\title{
Preliminary Study: An Investigation on Learning Assistance Requirement among Low Achievers in Primary Schools
}

\author{
Siti Zulaiha Ahmad \\ Universiti Teknologi MARA (Perlis) \\ Faculty of Computer and Mathematical Sciences \\ 02600 Arau, Perlis
}

\author{
Ariffin Abdul Mutalib \\ Universiti Utara Malaysia \\ School of Multimedia Technology and \\ Communication \\ Sintok, Kedah
}

\begin{abstract}
Learning is crucial for everybody regardless of their ability and achievement. Some children demonstrate inability in academic performance from their early stage of learning process; thus, categorized as low achievers (LA). In order to define learning difficulties and requirements among LA children, a qualitative study was conducted using three different techniques; i) semi- structured interview, ii) document review with LINUS content experts and iii) observation with students from five schools in Kedah and Perlis. The results reveal that, the LA children need a specific computer-based learning assistance as an alternative learning material to facilitate their learning process. Learning concepts are also discussed as an initial suggestion in this study.
\end{abstract}

\section{Keywords}

Low achievers, LINUS, learning assistance, computer-based learning application, courseware

\section{INTRODUCTION}

Low achievers (LA) or slow learners refers to students with low cognitive ability to grasp fundamental knowledge in the mainstream education system [1]. Students of this category usually struggle to carry on with normal learning process and teachers have to teach them based on their ability. Currently, the Ministry of Education (MoE) of Malaysia implements Literacy and Numeracy Screening (LINUS) test to identify these students. Based on this test, teachers will determine whether the child's competency in languages (Malay Language and English Language) and numeracy (Mathematics) using a standard test instrument. Eventually, children who are incompetent in the test will be categorized as LINUS students and treated in a special class, namely, 'LINUS Remedial Class'. The objective of this program is very clear, which is to give them a proper learning process [2].

The learning process of this group needs to be supported by specific learning tools. It is important to provide them with learning assistance in order to give them an attractive and attentive learning environment [3]. Currently, most of the learning tools are based on traditional learning materials, which are provided by the MOE, and teachers will fully utilize the materials using their own creativity and initiative. However, solely depending on this learning materials alone is insufficient as children will easily get bored and have low interest to proceed with the learning process [4]. Therefore, this study investigates learning assistance requirements that address LA children's needs by considering their learning problems and preferences.
The aim of this study is to provide the LA children with a proper learning assistance using technological advancement in education. There are many alternatives of teaching and learning technology that can be used to facilitate the teachers and students. It needs a thorough study to define and propose a suitable learning concept with technology assistance.

The initial stage of this study focuses on the information gathering of two different aspects. The first aspect is the learning difficulties faced by the LA children and the second aspect focuses on the learning concept suitable for them. Accordingly, at the end of the study, the existing scenario of LA learning environment and availability of computer based learning assistance in Malaysian education context will be revealed.

For in depth elaboration, the paper is presented in four main sections. In the first section, Research Background will discuss the current and related studies and this is followed by the Methodology section which explains the procedure of the study that has been conducted. The following section is Result Analysis, which emphasizes the outcome of the preliminary study. Some result discussions are included in the Discussion section which is prior to the Conclusion section.

\section{RESEARCH BACKGROUND}

\subsection{Low Achieving Students}

Poor learning ability gives problematic implication in the process of knowledge discovery among school children. LA students are categorized in this group regardless of their education level. According to [1], this category of children are not categorized as having learning disabilities and they are not entitled to be allocated in special education class. However, teachers have to give a proper attention to them as these children are clearly unable to acquire understanding in most of the subjects, especially language and mathematics in normal class sessions.

Learning characteristics of LA children can obviously be seen in the learning session in class as they possess low ability to grasp fundamental knowledge [5], perform poorly in standardized examinations [6] and lack of motivation [7] during learning process. In order to group them in similar characteristic of students, they are usually placed in the last ranked class.

A similar problem can be seen based on the observations that have been made when the children have test in year one, two and three. Some of them cannot even read the questions and write the answers properly, which make them unable to complete the test. According to the teachers, these children often lose focus and are easily distracted during the learning 
process when the teacher uses common learning tools such as books, exercise sheets, flash cards and whiteboard.

The consequences of this situation are that it will also affect their achievement in Primary School Achievement Test (Ujian Penilaian Sekolah Rendah-UPSR), as observed from 2010 to 2012 results in Table 1. The total number of students with poor results (D and E) for all subjects exceeds 100,000 students, which conveys a worrying situation faced by the Malaysian Education System and the students themselves [8].

Table 1. Number and percentage of candidates with below minimum competency (D and $E$ for all subjects) in UPSR examination from 2010 to 2012

\begin{tabular}{lccc}
\hline & 2010 & 2011 & 2012 \\
\hline Number of Candidates & 482,333 & 485,160 & 503,928 \\
$\begin{array}{l}\text { Number of candidates } \\
\text { with below minimum } \\
\text { competency level }\end{array}$ & 171,728 & 170,127 & 171,944 \\
$\begin{array}{l}\% \text { of candidates with } \\
\text { below minimum } \\
\text { competency level }\end{array}$ & $35.6 \%$ & $35.1 \%$ & $34.1 \%$ \\
\hline
\end{tabular}

Source: Malaysia Educational Statistics, Ministry of Education Malaysia, 2013

There are many factors implicating the examination achievement besides the cognitive ability in student themselves [9]. In accordance, MoE has taken an initiative by introducing LINUS Program to identify problematic students and provide them with specific educational program.

\subsection{LINUS Program}

In Malaysia, students who are incompetent in mastering literacy and numeracy concepts remain as a national issue in primary education level $[6,9]$. It leads to the enforcement of three basic skills known as $3 \mathrm{M}$ which refers to reading, writing and arithmetic, in order to prepare the students to the next level of the education system. However, as reported in Literacy and Numeracy by Performance Management and Delivery Unit (PEMANDU), drop-outs rate in 2008 was 31,939 , which is quite high in number [10].

Therefore, MOE has implemented many initiatives to make sure these children were able to master these skills by introducing Early Intervention Program for Writing and Reading (Kelas Intervensi Awal Membaca dan Menulis KIA2M) for literacy in 2006 and 3M Remedial Programme
(Program Pemulihan 3M-PROTIM) for numeracy in 2008. Based on the assessment of schools in 2008, they found that more than 54,000 students from year one and more than 110,000 from year four had not reached the target for literacy and numeracy standard, respectively [10]

This led to the introduction of LINUS programme that began in the year 2010, which was endorsed under National Key Area Result (NKRA) education mandate. This remedial program was designed to ensure competency of each student in Malay language (Bahasa Malaysia) and arithmetic (Mathematics).

The assessment is conducted twice a year with the main target to ensure every student masters literacy and numeracy skills after three years of their primary education as stated in Education NKRA. In 2012, MoE has included the English Language as part of LINUS assessment that highlights English literacy skills among year one students. All students, regardless of their scholastic ability will go through the screening test to identify learning problems faced by them. Those who have difficulties to grasp the fundamental knowledge of these three components will be endorsed in a specific remedial class.

In order to provide them with effective learning methods, MoE has developed modules in the form of books that can be used by teachers during the remedial session. Other learning alternatives will be based on the LINUS teachers' initiatives. In line with that, $\mathrm{MoE}$ also encourages teachers to implement creative teaching methods, including the use of information communication technology (ICT) as learning assistance for LA children.

\section{METHODOLOGY}

This study is conducted using qualitative method, which consists of three main stages. The first stage is literature exploration followed by information gathering as the second stage and the last stage is information analysis. Further it is seen in Figure 1 that each stage comprises of activities and techniques that are required to be accomplished in the study.

Stage 1: Literature Exploration: In the first stage, numerous literature has been reviewed and summarized to obtain an understanding of LA children and LINUS program. Based on the initial information collected from the literature, semi structured questions were designed as an interview instrument. This instrument was used to gather information from LINUS coordinators and teachers who are the content experts in five selected schools in Kedah and Perlis. Accordingly, Table 2 lists the questions prepared for the interview session. 


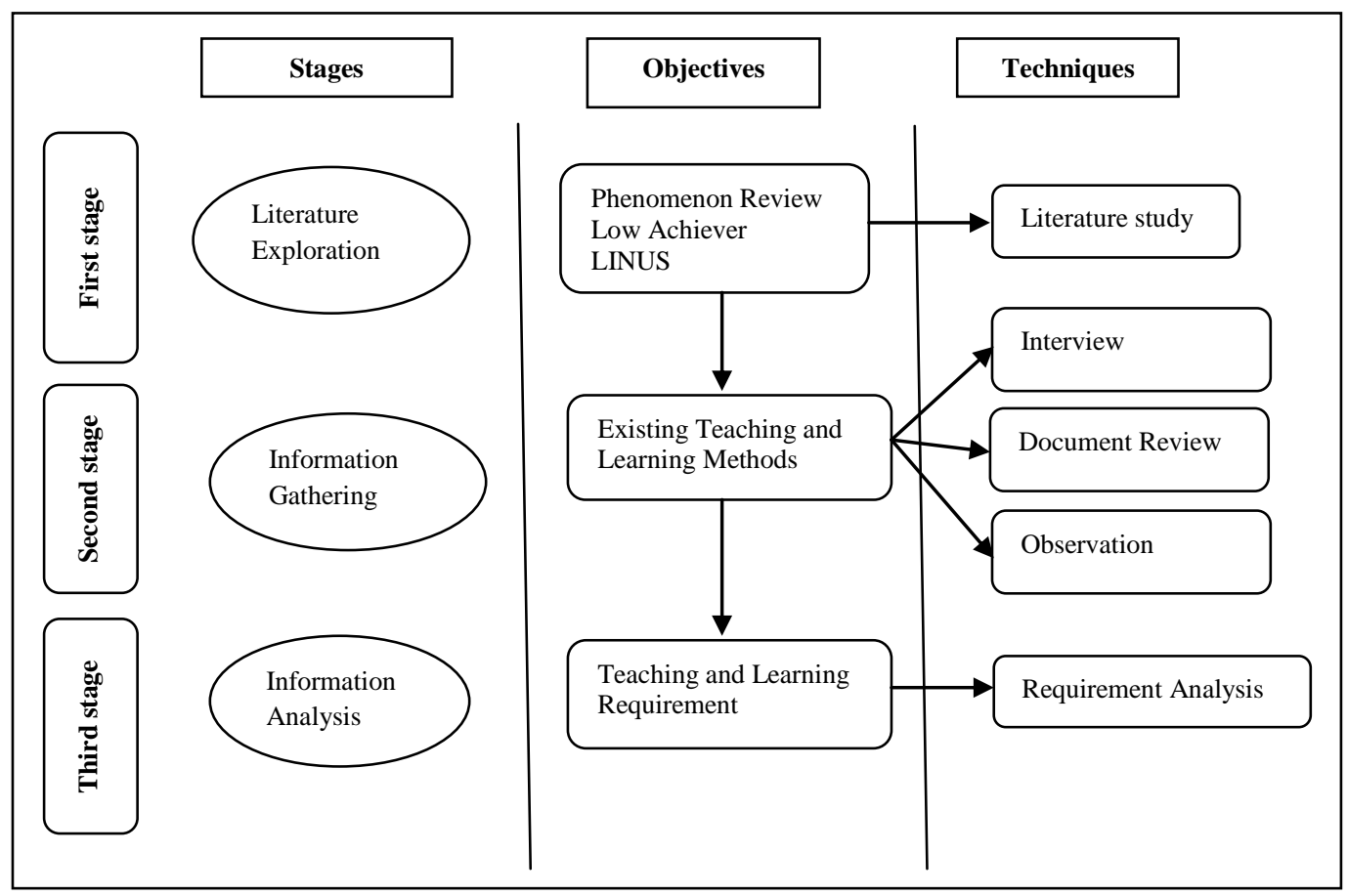

Fig 1. Methodology of the study

Table 2:.List of interview questions

No Items
Q1 What the main problems that appear in LA children?
Q2 Why do these problems occur?
Q3 Is there any remedial program conducted in school?
Q4 What are the remedial programs that have been
conducted?

Q5 Do teachers use additional learning materials to teach LA children besides LINUS module?

Q6 Is there any learning tool (ICT application) used in teaching and learning of these children?

Q7 Is the courseware provided in text books suitable for LA children?

Q8 Are the LA children exposed to multimedia learning coursewares available in the market?

Q9 Are those coursewares accessible and suitable for LA children?

Q10 Is there any special courseware designed for LA children that can be used in LINUS program?

Q11 Do you recommend that a proper learning courseware be specifically designed for LA children?

Stage 2: Information Gathering: The second stage of this study was conducted in five schools located in Perlis and Kedah. Permission has been obtained from the State
Education Department of Perlis and District Education Center, Kubang Pasu Kedah prior to the field study. The main objectives of this session are to discover the existing teaching and learning methods and the real problems faced by the students and teachers. This is important to ensure the richness of data and to reveal existing learning environment. Field (in classroom) observation has been conducted in order to provide exhaustive information of students' learning behavior and experience in class. In addition, LINUS test results were reviewed to analyze students' performance in the Malay Language, English Language, and Mathematics of Year 1, 2 and 3 students. Collected data were then analyzed, and in the third stage identification of learning concept that is suitable for the students was carried out.

Stage 3: Information Analysis: Requirement analysis is the main technique used in this stage. All collected data were summarized in order to investigate the fundamental problems at school level. It is essential to reveal the similarities and differences of problems and learning preferences of each school as these are useful in identifying a suitable learning concept.

Based on the above study procedures, the collected and analyzed data are presented in the next section.

\section{RESULT ANALYSIS}

The analysis section is divided into three subtopics that present LINUS test result based on document review, LA childrens' learning problems, and existing learning methods or concept conducted by teachers based on interview sessions and learning behavior based on observations in the five schools. SK A, SK B, SK C and SK D are the selected school from Perlis. SK E is a cluster school in Kedah that has been chosen as a comparison to the four schools in Perlis.

\subsection{LINUS Result}

LINUS test questions are designed according to respective student grade (Year 1, 2 and 3) and divided into three different sets; Bahasa Malaysia (BM-literacy), English (literacy) and Mathematics (numeracy). According to the 
teachers, LINUS test is a guided test which means that teachers will give instruction to the students to answer the given questions and those who wrongly answer any of the questions will be considered incompetent.

Table 3 shows a summary of data extracted from LINUS result documents based on initial screening test conducted from the year 2012 to 2014 in five schools. However, due to confidentiality reason, the LINUS result is presented as an overall result for five schools. English LINUS result was only available for the year 2014, its year of commencement. Screening results show that Year 1 students are more problematic in literacy compared to numeracy concept with more than $33 \%$ incompetency of BM for all the three years and $47 \%$ failure in English. However, deficiency of numeracy concept among Year 1 and Year 2 students is worrying as the percentage of students who were unable to fulfill the minimum requirement of the test as depicted in Figure 2 were reasonably high. Even though the rates of failure in year 2 and 3 show a decreasing pattern, incompetent students still exist. Based on LINUS result analysis, further investigations have been conducted to reveal LA children learning problems which are discussed in the next section.

Table 3. LINUS test result

\begin{tabular}{|c|c|c|c|c|c|c|c|c|}
\hline School & Subject & \multicolumn{3}{|c|}{ Bahasa Malaysia (BM) } & \multicolumn{3}{|c|}{ Mathematics } & English \\
\hline \multirow{4}{*}{$\begin{array}{l}\text { SK A, SK B, } \\
\text { SK C, SK D } \\
\& \text { SK E }\end{array}$} & Year & 2012 & 2013 & 2014 & 2012 & 2013 & 2014 & 2014 \\
\hline & Year 1 & $33 \%$ & $34 \%$ & $41 \%$ & $25 \%$ & $14 \%$ & $17 \%$ & $47 \%$ \\
\hline & Year 2 & $9 \%$ & $12 \%$ & $13 \%$ & $16 \%$ & $7 \%$ & $11 \%$ & $33 \%$ \\
\hline & Year 3 & $0 \%$ & $3 \%$ & $7 \%$ & $0 \%$ & $1 \%$ & $4 \%$ & - \\
\hline
\end{tabular}

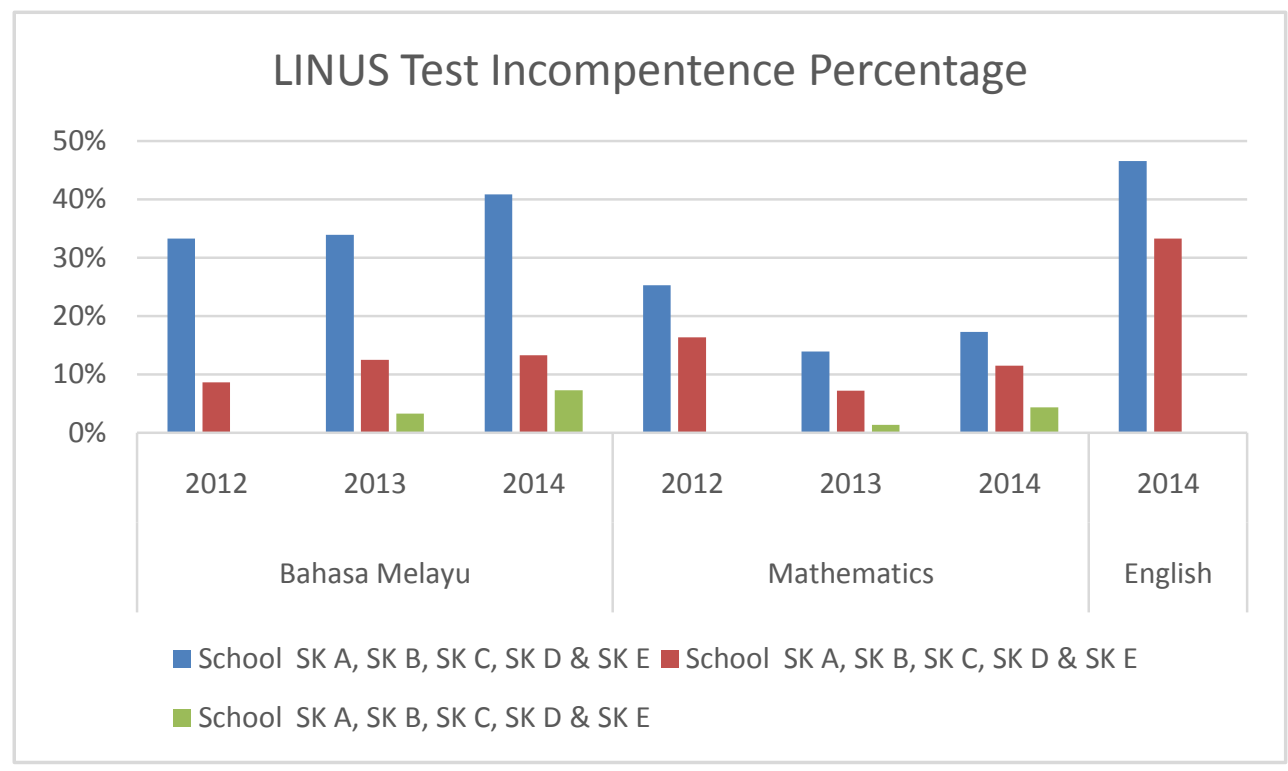

Fig 2. Comparison of LINUS test by years and subjects

\subsection{Learning Problems of LA Children}

Learning problems among LA children could distract their learning progress. Based on the interview sessions with all respondents for questions 1 and 2 (Q1 and Q2) and observations, the learning problems shown in Table 4 have been identified. The symbol (/) means respondent is agree with the item.

Table 4. Summary of problems

\begin{tabular}{|l|l|l|l|l|l|l|}
\hline & $\begin{array}{l}\text { Problem } \\
\text { identified }\end{array}$ & $\begin{array}{l}\text { SK } \\
\text { A }\end{array}$ & $\begin{array}{l}\text { SK } \\
\text { B }\end{array}$ & $\begin{array}{l}\text { SK } \\
\text { C }\end{array}$ & $\begin{array}{l}\text { SK } \\
\text { D }\end{array}$ & $\begin{array}{l}\text { SK } \\
\text { E }\end{array}$ \\
\hline P1 & $\begin{array}{l}\text { Lack of focus } \\
\text { during learning } \\
\text { sessions }\end{array}$ & $/$ & $/$ & $/$ & $/$ & $/$ \\
\hline
\end{tabular}

\begin{tabular}{|l|l|l|l|l|l|l|}
\hline P2 & $\begin{array}{l}\text { Lack of } \\
\text { motivation }\end{array}$ & $/$ & $/$ & $/$ & $/$ & $/$ \\
\hline P3 & $\begin{array}{l}\text { Have a short } \\
\text { memory span }\end{array}$ & $/$ & $/$ & $/$ & $/$ & $/$ \\
\hline P4 & $\begin{array}{l}\text { Have poor } \\
\text { basic reading } \\
\text { skills / }\end{array}$ & $/$ & $/$ & $/$ & $/$ \\
\hline P5 & $\begin{array}{l}\text { Have poor } \\
\text { basic K1 and } \\
\text { K2 construct in } \\
\text { Maths }\end{array}$ & $/$ & $/$ & $/$ & $/$ \\
\hline
\end{tabular}




\begin{tabular}{|c|c|c|c|c|c|c|}
\hline P6 & $\begin{array}{l}\text { Problematic } \\
\text { learning } \\
\text { behavior }\end{array}$ & I & I & I & & I \\
\hline P7 & $\begin{array}{l}\text { Need guided } \\
\text { instruction-one } \\
\text { to } \\
\text { guidance }\end{array}$ & I & I & I & & I \\
\hline P8 & $\begin{array}{l}\text { Have writing } \\
\text { problem }\end{array}$ & I & I & I & & I \\
\hline P9 & $\begin{array}{l}\text { Fail to } \\
\text { understand } \\
\text { instructions }\end{array}$ & & & I & I & I \\
\hline P10 & $\begin{array}{l}\text { Do not attend } \\
\text { pre-school }\end{array}$ & I & I & I & & \\
\hline P11 & $\begin{array}{l}\text { Poor in basic } \\
\text { math } \\
\text { operations }\end{array}$ & & I & I & I & \\
\hline P12 & $\begin{array}{l}\text { Problematic } \\
\text { learning } \\
\text { attitude }\end{array}$ & I & I & & & I \\
\hline P13 & $\begin{array}{l}\text { Lack of family } \\
\text { support }\end{array}$ & I & I & & & \\
\hline P14 & $\begin{array}{l}\text { Have a poor } \\
\text { attendance } \\
\text { record }\end{array}$ & & I & & & \\
\hline
\end{tabular}

Referring to the results in Table 4, responses from the teachers regarding the students' problems are mainly related to motivational and cognitive aspects. Almost all respondents agreed that P1, P2, P3, P4 and P5 are the main contributors to low achievement in academic. This is also proven by the LINUS test results in Table 3, especially for Year 1 and Year 2 students. According to the teachers of SK A, SK B, SK C, and SK E, most of the children needed a closer guidance (P7) from the teachers in order to complete the given tasks as they hardly understood written instructions (P9) and were unable to write properly (P8). It shows that personalize verbal instructions are important during the learning process. Those problems were initially caused by several factors such as did not attend pre-school session (P10), lack of family support (P13), learning attitude problems (P12) which led to poor understanding in particular subjects (P11). However, not all respondents agreed with these factors because they believed that those children needed special attention to attract their interest. Therefore, the study was further expanded to investigate existing learning methods and learning assistance to support the teaching and learning process.

\subsection{Existing Learning Concept and \\ Assistance}

Learning methods are important and must be customized based on learners' abilities. From the interviews as summarized in Table 5, it is understood that all schools have conducted remedial class $(\mathrm{Q} 3, \mathrm{Q} 4)$ for the children as required by the MoE. In addition, some of the schools organized extra classes with the parents, Maths Clinic, weekly special program for Malay and English literacy.

Table 5. Summary of learning concept and assistance

\begin{tabular}{|c|c|c|c|c|c|c|}
\hline & $\begin{array}{l}\text { Learning concept } \\
\text { and assistance }\end{array}$ & $\begin{array}{l}\text { SK } \\
\text { A }\end{array}$ & $\begin{array}{l}\text { SK } \\
\text { B }\end{array}$ & $\begin{array}{l}\text { SK } \\
\text { C }\end{array}$ & $\begin{array}{l}\text { SK } \\
\text { D }\end{array}$ & $\begin{array}{l}\text { SK } \\
\text { E }\end{array}$ \\
\hline L1 & $\begin{array}{l}\text { LINUS } \\
\text { workbook }\end{array}$ & l & l & l & I & I \\
\hline L2 & LINUS class & l & I & I & I & l \\
\hline L3 & Extra exercises & I & l & l & & / \\
\hline L4 & $\begin{array}{l}\text { Extra classes } \\
\text { with parents }\end{array}$ & & I & & & \\
\hline L5 & Computer games & & & l & & \\
\hline L6 & Maths Clinic & & l & & & \\
\hline L7 & $\begin{array}{l}\text { Electronic } \\
\text { materials } \\
\text { prepared by the } \\
\text { teacher }\end{array}$ & & & I & & \\
\hline L8 & Flash Cards & & & I & & I \\
\hline L9 & $\begin{array}{l}\text { Multisensory- } \\
\text { touch, hear \& } \\
\text { see (non ICT) }\end{array}$ & & & I & & \\
\hline L7 & $\begin{array}{l}\text { Adapt learning } \\
\text { syllabus based } \\
\text { on performance }\end{array}$ & & & & I & \\
\hline L8 & $\begin{array}{l}\text { Special } \\
\text { Programs }\end{array}$ & & & & & / \\
\hline
\end{tabular}

The above remedial programs were conducted by the teachers. Table 6 lists samples of the responses transcribed during the interview sessions with the respondents which reflected on the program.

Table 6. Samples of respondents' responses

\begin{tabular}{|l|l|}
\hline R\# & Responses \\
\hline R1 & $\begin{array}{l}\text { "Most of us only use LINUS workbook to teach } \\
\text { them (LA children) and sometimes using cards " }\end{array}$ \\
\hline R2 & $\begin{array}{l}\text { " I take my own initiative to create learning } \\
\text { materials such as flash cards, computer } \\
\text { games..." }\end{array}$ \\
\hline R3 & $\begin{array}{l}\text { "I am using touch, hear and visual sense to } \\
\text { make the children recognize the letters } \\
\text { (characters)..." }\end{array}$ \\
\hline R4 & $\begin{array}{l}\text { "I let them use computer to attract their interest } \\
\text { during the remedial class session..." }\end{array}$ \\
\hline
\end{tabular}




\begin{tabular}{|l|l|}
\hline R5 & $\begin{array}{l}\text { "The children need face to face learning and } \\
\text { someone to guide them..." }\end{array}$ \\
\hline R6 & $\begin{array}{l}\text { "For low achievers or LINUS children the } \\
\text { courseware from text book may be not } \\
\text { suitable..." }\end{array}$ \\
\hline
\end{tabular}

Most of them agree that they are provided only with LINUS workbook by the MoE. The workbook consists of several volumes which contain graphical images with different methods of learning concept. Instead of using them, some teachers take their own initiative (Q5) to enrich the learning materials based on their creativity such as by creating flash cards, presentation slides, educational computer games and extra exercises. Computer based learning is rarely used because lack of specific application or courseware created for the remedial class and the provided courseware from text book is not really suitable for them $(\mathrm{Q} 7, \mathrm{Q} 10)$. In order to confirm these matters, further questions were asked to the respondents.

As shown in Table 7, all interviewees agreed that most of these children were not exposed to the courseware in the market as it is not available at school and not suitable with LA children's level (Q8, Q9). MoE has introduced Frog VLE application, but it needs web based e-learning skill which is lacking in most LA children, even if they are IT literate children. Based on the respondents' feedback, all of them agreed that they required teaching and learning assistance specifically designed and created for LA children. Responses from the participants who are also LINUS teachers revealed that adaptation of learning concept in the form of computer based learning material is important to promote fun learning experience (Q11).

Table 7. Summary of courseware availability and needs

\begin{tabular}{|c|c|c|c|c|c|}
\hline Item & $\begin{array}{l}\text { SK } \\
\text { A }\end{array}$ & $\begin{array}{l}\text { SK } \\
\text { B }\end{array}$ & $\begin{array}{l}\text { SK } \\
\text { C }\end{array}$ & $\begin{array}{l}\text { SK } \\
\text { D }\end{array}$ & $\begin{array}{l}\text { SK } \\
\text { E }\end{array}$ \\
\hline $\begin{array}{l}\text { Is the courseware } \\
\text { accessible } \\
\text { suitable for LA } \\
\text { children? }\end{array}$ & & & & & \\
\hline $\begin{array}{l}\text { Is the courseware } \\
\text { generally designed } \\
\text { for all students? }\end{array}$ & I & I & I & I & I \\
\hline $\begin{array}{l}\text { Is there any } \\
\text { courseware designed } \\
\text { specifically for LA } \\
\text { children's needs? }\end{array}$ & & & & & \\
\hline $\begin{array}{l}\text { Do teachers need } \\
\text { special courseware } \\
\text { designed for LA } \\
\text { students? }\end{array}$ & I & I & I & I & I \\
\hline
\end{tabular}

\section{DISCUSSION}

In line with the findings from the previous section, this study is directed to explore the learning concept that is subjected to the learning characteristics of LA children. This is important to discover the learning assistance requirements that could facilitate their learning process. In this early stage, this study makes an attempt to look into active learning concept and multisensory learning approach. The main concern is to encourage and engage the LA children with interactive and innovative learning environment by applying both concepts.

Active learning is an approach that will trigger an initiative in learners to experience learning by participating in the activities conducted in the classroom [11] and it is effectively used in multimedia learning environment [12, 13, 14]. Active learning approach is beneficial for learners to gain experience by incorporating activities such as doing, observing, writing, reading and listening during the learning process [15]. The learning content of such concept can trigger and stimulate the learners' ability to react and think as they have to participate actively in the learning environment. Even though active learning promotes high skills of thinking ability such as analysis, synthesis and evaluation [15, 16, 17], enforcement can be done in a small scale of the subject being taught. This can be implemented through fun and entertaining ways for instance game based learning [17] and role play [16] which are in line with learning characteristics of LA children.

The active learning approach will be incorporated with multisensory approach so that children with learning difficulties can actively use their senses to engage in learning. Multisensory approach is also useful to attain learners' focus as they have problem to concentrate during learning. The multisensory learning approach consists of strings of multisensory strategies (linking of eyes, ears, and voice and hand movements) and has been proven to be effective towards children with learning disabilities (dyslexia children) in previous studies $[18,19,20]$. Therefore, multisensory and active learning can be considered as part of theoretical study in learning approach that will be adapted in this study, in order to explore its effectiveness as LA children learning assistance.

\section{CONCLUSION}

This study explored the problem of LA children and investigated existing learning assistance that are related to computer-based learning application in primary school environment. The main problems found in LA children are mainly related to poor cognitive ability and self-motivational learning concept which affect their academic achievement. It is consistent with previous study [7] that stated motivation is the main contribution to their under achievement in study. Based on the interview results, it can be concluded that the existence of computer-based learning assistance that practically supports learning process of LA children is still at an infancy stage. In addition, it shows that teachers also require an alternative teaching material besides the provided module.

Basically, LA children need additional learning assistance that could facilitate and motivate them in daily learning activities. Learning concept and approach that have been discussed in previous sections are considered based on the successful implementation in different settings. The outcome of the preliminary study is the initial step to identify the requirements of LA children in defining a suitable learning assistance concept. Therefore, further study is crucial in determining a comprehensive learning component that should be included in the proposed computer-based learning application as suggested by the content experts and previous studies. 


\section{ACKNOWLEDGEMENT}

The authors would like to acknowledge Universiti Teknologi MARA Malaysia (UiTM), Malaysian Education Ministry (MoE) and Universiti Utara Malaysia (UUM) for their support in this study. Also, special thanks go to all teachers and principals that were directly and indirectly involved in the information gathering stage.

\section{REFERENCES}

[1] Malik, S. (2009). Effect of Intervention Training on Mental Abilities of Slow Learners. International Journal of Education Science, 1(1), 61-64.

[2] Ahmad, W. F. W., Noordin, M. S., \& Shariffuldin, N. S. M. (2013). Development of a Multimedia Courseware for Slow Learner Children with Reading Difficulties: MyLINUS. In Raul A. Herrera-Acuña, V. Argyriou, S. A. Velastin, H. B. Zaman, P. Robinson, P. Olivier, \& T. K. Shih (Eds.), 3rd International Visual Infomatics Conference 2013 (pp. 371-382). Springer International Publishing Switzerland 2013.

[3] Adam, T., \& Tatnall, A. (2010). Use of ICT to assist students with learning difficulties an Actor-Network analysis. In N. Reynolds \& M. Turcsanyi-Szabo (Eds.), IFIP Advances in Information and Communication Technology (pp. 1-11). Springer Berlin Heidelberg New York.

[4] Hoon, T. S., Chong, T. S., Ngah, N. A., \& Kee, K. L. (2009). The effectiveness of an interactive courseware. In Proceeding of ICICTE 2009 (pp. 530-541).

[5] Lau, K.-L., \& Chan, D. W. (2001a). Identification of Underachievers in Hong Kong: Do different methods select different underachievers? Educational Studies, 27(2), 187-200. doi:10.1080/03055690120050419

[6] Sani, N., \& Idris, A. R. (2013a). Implementation Of Linus Programme based on the Model of Van Meter and Van Horn. The Malaysian Online Journal of Educational Science, 1(2), 25-36.

[7] Lau, K.-L., \& Chan, D. W. (2001b). Motivational Characteristics of Under-achievers in Hong Kong. Educational Psychology, 21(4), 417-430. doi:10.1080/01443410120090803

[8] Azmi, N. I., Hisyam, M., \& Hashim, M. (2013). Amalan pengajaran berkesan dalam pendidikan asas vokasional di sekolah menengah kebangsaan harian : Dapatan kajian rintis. In 2nd International Seminar on Quality and Affordable Education (ISQAE 2013) (pp. 342-348).

[9] Sani, N., \& Idris, A. R. (2013b). Identifying the challenges encountered by teachers in dealing with indigenous students. Malaysian Online Jornal of Educational Management, 1(3), 48-63.

[10] PEMANDU (Performance Management and Delivery Unit). (n.d.). Literacy and Numeracy: Education NKRA
Lab. $\quad$ Retrieved from http://www.academia.edu/6442260/Literacy_and_Numer acy_Education_NKRA_Lab_Introduction_to_Literacy_a nd_Numeracy_sub-NKRA

[11] Yetsko, K., Licitra, J., \& Armstrong, T. (2005). Encouraging active learning through multimedia \& interactive courseware. In Proceedings Frontiers in Education 35th Annual Conference (pp. S2D-10-S2D16). IEEE. doi:10.1109/FIE.2005.1612221

[12] Azemi, A. (1997). Developing an active learning environment with courseware approach. In Proceedings Frontiers in Education 1997 27th Annual Conference. (Vol. 3, pp. 1179-1184). IEEE XPLORE doi:10.1109/FIE.1997.632627

[13] Schank, R. C. (1994). Active learning through multimedia. IEEE Multimedia, 1(1), 69-78. doi:10.1109/93.295270

[14] Sorden, S. D. (2012). The cognitive theory of multimedia learning. In Handbook of Educational Theories (pp. 131). Charlotte, NC: Information Age Publishing. Retrieved from http://sorden.com/portfolio/sorden_draft_multimedia201 2.pdf

[15] Ariffin, A. M. (2009). Conceptual design of Reality Learning Media (RLM) model based on entertaining and fun constructs. Universiti Utara Malaysia. Retrieved from http://etd.uum.edu.my/1521/

[16] Michael, J. (2006). Where's the evidence that active learning works? Advances in Physiology Education, 30(4), 159-67. doi:10.1152/advan.00053.2006

[17] Miller, C. J., \& Metz, M. J. (2014). A comparison of professional-level faculty and student perceptions of active learning: its current use, effectiveness, and barriers. Advances in Physiology Education, 38(3), 24652. doi:10.1152/advan.00014.2014

[18] Daud, S. M., \& Abas, H. (2013). "Dyslexia Baca" mobile app -- The learning ecosystem for dyslexic children. In 2013 International Conference on Advanced Computer Science Applications and Technologies (pp. 412-416). IEEE. doi:10.1109/ACSAT.2013.87

[19] Kast, M., Meyer, M., \& Christian, V. (2007). Computerbased multisensory learning in children with developmental dyslexia. Restorative Neurology and Neuroscience, 25, 355-369. Retrieved from http://iospress.metapress.com/content/p13318mg006174 w7/

[20] Sidhu, M. S., \& Manzura, E. (2011). An effective conceptual multisensory multimedia model to support dyslexic children in learning. International of Information and Communication Technology Education, 7(3), 34-50. doi:10.4018/jicte.2011070104 